\title{
HISTOCHEMICAL CHARACTERISTICS OF THE SPLAYLEG SYNDROME IN NEWBORN PIGLETS*
}

\author{
Z. LUKÁS̆,1) J. KAMAN, L. PIVNÍK \\ II. Department of Pathology, Children's Hospital, 66263 Brno; \\ Department of Pathological Morphology and Parasitology, University of Veterinary Science, \\ 61242 Brno
}

Received Fanuary 23, 1978

\begin{abstract}
Lukáš Z., Kaman J., Pivník L.: Histochemical Characteristics of the Splayleg Syndrome in Newborn Piglets. Acta vet., Brno, 47, 1978: 51-66.

Histological examinations of the muscles extensor carpi radialis, pectoralis superficialis, triceps brachii, gracilis, adductor, biceps femoris, and longissimus dorsi were carried out in 9 piglets with "splayleg" syndrome associated with myofibrillar hypoplasia, and in four piglets without clinical symptoms from the same breed, all of them aged $1-3$ days. In addition to routine staining, histochemical reactions were performed for $\mathrm{Ca}^{2+}$-ATPase ( $\mathrm{pH}$ 9.4), NADH-tetrazolium reductase, acid phosphatase, non-specific esterase, cholinesterase, glycogen and lipids.

Non-affected extrafusal fibres showed two reaction intensities for $\mathrm{Ca}^{2+-A T P a s e: ~}$ an intensive reaction in fibres located mostly on the periphery of primary bundles, and a fainter reaction in fibres located closer to the centre demonstrated the incipient type differentiation of the fibres.

Such a distinction was only possible by means of the NADH-tetrazolium reductase reaction. The localization was evidently mitochondrial and intensive reaction was also to be observed on the periphery of some fibres located in the centre of primary bundles. Reactions for glycogen and lipids were generally equal in all fibres. Azo-dye reactions with alpha-naphthylacetate and histochemical detection of acetylcholinesterase demonstrated regularly distributed and normally shaped motor- end plates. Intrafusal fibres showed an intensive, mostly uniform reaction for NADH-tetrazolium reductase, and a strong gradual reaction for $\mathrm{Ca}^{2+}$-ATPase.

In deficient regions fibre type differentiation was less pronounced but it is the second population of fetal myofibres that seems to be affected by MHF.

Glycogen was accumulated in spaces defficient in myofibrils. Neither size and shape nor distribution of motor end-plates were altered. No deficiency of myofibrils and no changes of the reactions under study were observed in intrafusal fibres.
\end{abstract}

Splayleg syndrome, myofibrillar hypoplasia, congenital reversible myofibrillar dysmaturity, newborn piglets, muscle fibre type differentiation, neuromuscular unit, histochemistry.

As in many countries with advanced pig breeding, typical causes of the losses of newborn piglets in Czechoslovakia in the last years are partly due to so called "splayleg" syndrome connected clinically with the weakness of leg muscles and morphologically above all with an insufficient, retarded development of myofibrils in muscle fibres of some skeletal muscles. At present, the

\footnotetext{
* This investigation received financial support from the World Health Organisation.
} 
syndrome is considered a hereditary disorder, which has a hereditary basis accompanying the creation of new meat breeds of pigs (Pivnik, Kaman 1974, 1975, 1977).

In the course of investigations carried out in 1973-1976, also histochemical examinations were performed in order to clarify pathogenesis of the disorder and to find out whether the nervous system on the level of the neuromuscular unit participated in some way in it.

Although the morphological background of "splayleg" syndrome was described as early as 1967 (Thurley, Gilbert, Done), the first reports on biochemical and histochemical findings appered considerably later (Thurley, Done 1969; Patterson, Allen 1972; Swatland 1974; Schlotke, Koch 1978). From the viewpoint of the nervous system on the level of the transmitting neuromuscular apparatus, no records could be found in available literature.

Most frequently and evidently affected is $\mathrm{m}$. longissimus dorsi, followed in alternating sequence by $\mathrm{m}$. gracilis, $\mathrm{m}$. quadriceps femoris, $\mathrm{m}$. semimembranosus, $\mathrm{m}$. gastrocnemius, $\mathrm{m}$. triceps brachii, m. semitendinosus and to a minor extent other muscles.

\section{Materials and Methods}

The animals examined were crossbred piglets (Czech White Large $\times$ Slovak White Meat Pig, Slovak White Meat Pig $\times$ Slovak White Meat Pig, Czech White Large $\times$ Landrace) with more or less plain symptoms and piglets in apparently good health, from breeds affected by "splayleg" syndrome.

A total of 13 piglets aged 1-3 days were examined in three groups: I. Six piglets with evident symptoms of disturbed motility; II. Three with less marked symptoms; III. Four animals without clinical symptoms.

From each piglet, the following muscles were examined: extensor carpi radialis, pectoralis superficialis, triceps brachii, gracilis, semimembranosus, resp. adductor, biceps femoris and $\mathrm{m}$. longissimus dorsi.

Material for histochemical examination was collected under general ether narcosis. The samples were immediately deep-frozen in propane-butane cooled by liquid nitrogen to $-160^{\circ} \mathrm{C}$. Deep frozen material was kept in store in solid carbon dioxide at $-70^{\circ} \mathrm{C}$. Cryostat slides were prepared and the part of them intended for staining (hematoxyline-eosine and van Gieson's) was fixed in $10 \%$ natural formol, while the rest of them were used for detection of $\mathrm{Ca}^{2+}+$-activated-ATPase, with or without acid preincubation, NADH-tetrazolium reductase, acid phosphatase, non-specific esterase and acetylcholinesterase.

Histochemical detection of ATPase was considered fundamental to identification of muscle fibre types. The detection was performed in the way described by Padykula and Herman (1956) in the gel modification (Lukáš, Dvořák 1977).

NADH-tetrazolium reductase, like SDH and other dehydrogenases, is a reliable marker of mitochondria or mitochondrial activity. It was detected by the usual tetrazolium technique.

Acid phosphatase and non-specific esterase are lysosomal enzymes, the activity of which, in muscle tissue or mesenchymal elements, can be of importance for diagnosis of inflammatory as well as myogenic lesions. Both enzymes were detected by the azo-dye method using alpha-naphthylacetate or alpha-naphthylphosphate as substrates and hexazo-p-rosaniline.

The reaction with alpha-naphthylacetate as well as the histochemical demonstration of acetycholinesterase (in agar-gel modification of Karnovsky and Roots' method - Lukáš, Fialová 1976) is suitable for the identification and evaluation of motor-end plates.

Glycogen was detected by the PAS reaction with and without digestion by salivary amylase, lipids were demonstrated by Sudan Black. Detailed information on the methods used was given by Lukáš and Dvořák (1977).

Fig. 1.

Non-affected muscle (m. extensor carpi radialis). Myosine-ATP-ase reaction in extrafusal fibres, pH 9.4. Fibres with intensive reaction are mostly on the periphery of primary bundles. Magnification $120 \times$.

Fig. 2.

Non-affected muscle (m. pectoralis superficialis). Perpendicular section of a neuromuscular spindle. Stained by hematoxyline-eosine. Appropriate structure and size of intrafusal and extrafusal fibres. Magnification $400 \times$. 

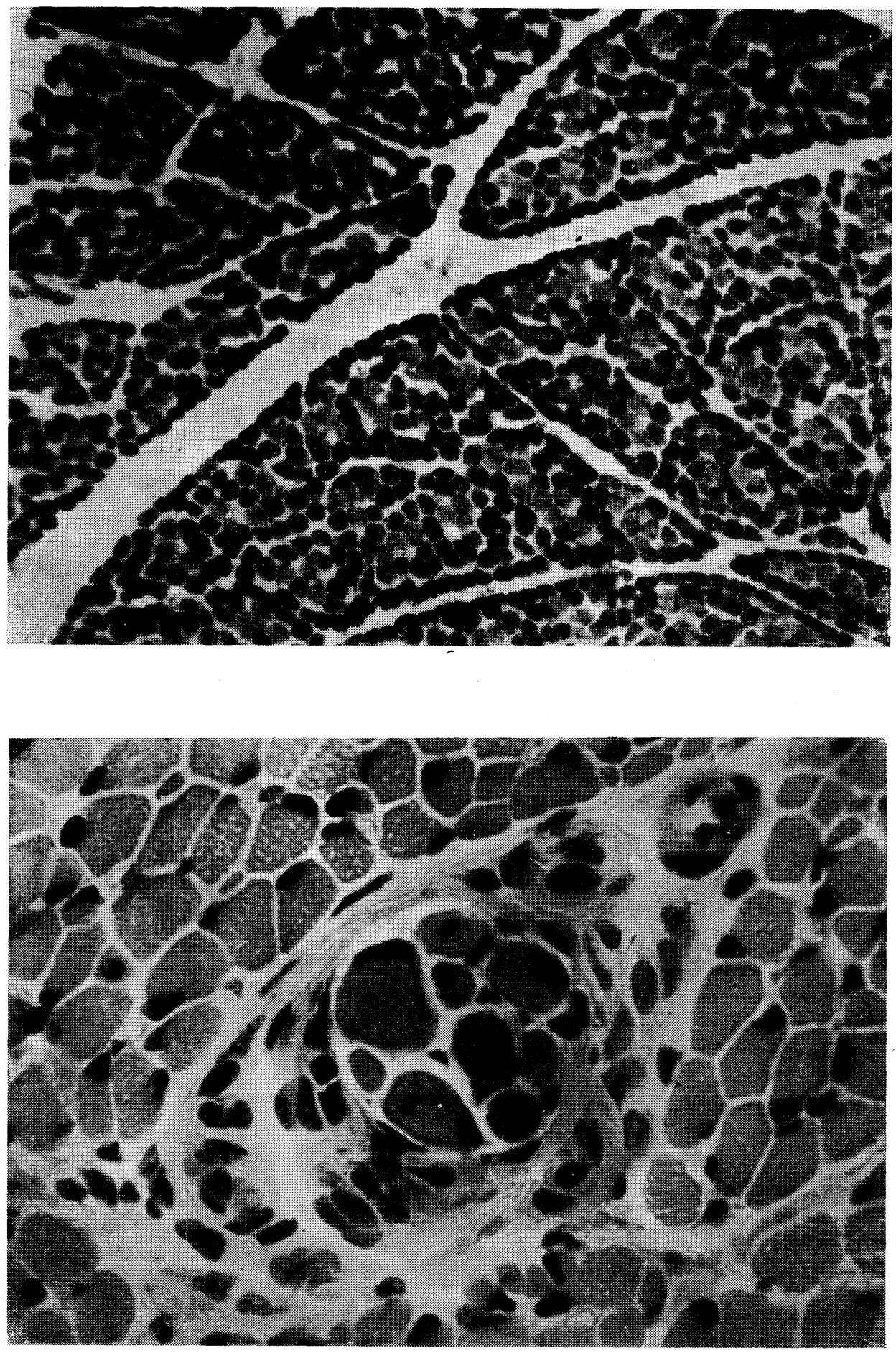


\section{Results}

Alterations characterized by deficiency of myofibrils were found in every group under study. An exception was one piglet from group II. (faint symptoms), with an entirely negative finding.

The largest proportion of affected muscles and the most evident alterations were in the group of piglets with the grave clinical symptoms, while in the rest the effect on muscles was considerably weaker.

1. Non-affected muscles (without myofibrillar deficiency) showed a certain variability in the diameter of fibres $(5-15 \mu \mathrm{m}$ - quantitative results will be reported in another paper). Most of the nuclei were sarcolemmatical, less often centrally located, and of oval or slightly flattened shape. Routinely stained sarcoplasm was homogenous (Fig. 1). The endomysium had a fine structure and extrafusal fibres fitted closely together, so that on the transversal cut of most bundles they had a polygonal shape, while in the rest of bundles they still maintained a rounded shape. Intrafusal fibres were of a similar size, their nuclei were as a rule located in the centre (Fig. 2).

Histochemical detection of $\mathrm{Ca}^{2+}$-ATPase: In 2/3-3/4 of samples, there were fibres with a stronger reaction, located at the periphery of primary bundles, and fibres reacting with less intensity, located in the centre (Fig. 1 and 5).

Intrafusal fibres could also be distinguished according to the intensity of the ATPase reaction in some muscle spindles while the reaction product was of equal intensity in others (Fig. 3).

NADH-tetrazolium reductase reaction intensity in extrafusal muscle fibres was approximately reciprocal to that of $\mathrm{Ca}^{2+-A T P a s e, ~ t h o u g h ~ t h e ~ d i f f e r e n c e ~ b e t-~}$ ween the two main types was less distinct. On the periphery of primary bundles the fibres were not too sharply demarcated, while numerous inner fibres showed a subsarcolemmal accumulation of the reaction product in addition to its mitochondrial localization. It is not clear whether capillary endothelium also participates in the reaction (Fig. 6). Intrafusal muscle fibres showed uniformly distributed and well demarcated reaction activity.

The reaction of motor-end plates detected by thiocholine (Fig. 7) or azo dye (Fig. 8) method was distinct. They had an uniform size $(8-10 \mu \mathrm{m})$ and regular distribution.

Lysosomal hydrolases (non-specific esterase and acid phosphatase in lysosomal localization) displayed in non-affected muscles a very slight and non-significant reaction limited to mesenchymal elements in the interstitium.

Muscle glycogen exhibited a regular intermyofibrillar localization of the PAS-reaction product, sudanophilic lipids were regularly distributed, too. There

Fig. 3.

Serial section to Fig. 2. Myosine-ATP-ase, pH 9.4. Two distinctly differentiated types of extrafusal muscle fibres. Intensity of reaction of intrafusal fibres is gradual, higher than in extrafusal fibres. Magnification $400 \times$.

Fig. 4.

Serial section to Fig. 2 and 3. NADH-tetrazolium reductase. Reaction of intrafusal fibres of high intensity, but no possibility of its differentiation. Generally lower intensity of reaction in extrafusal fibres, distinctly mitochondrial localization. No accumulation of reaction product on the periphery of fibres. Magnification $400 \times$. 

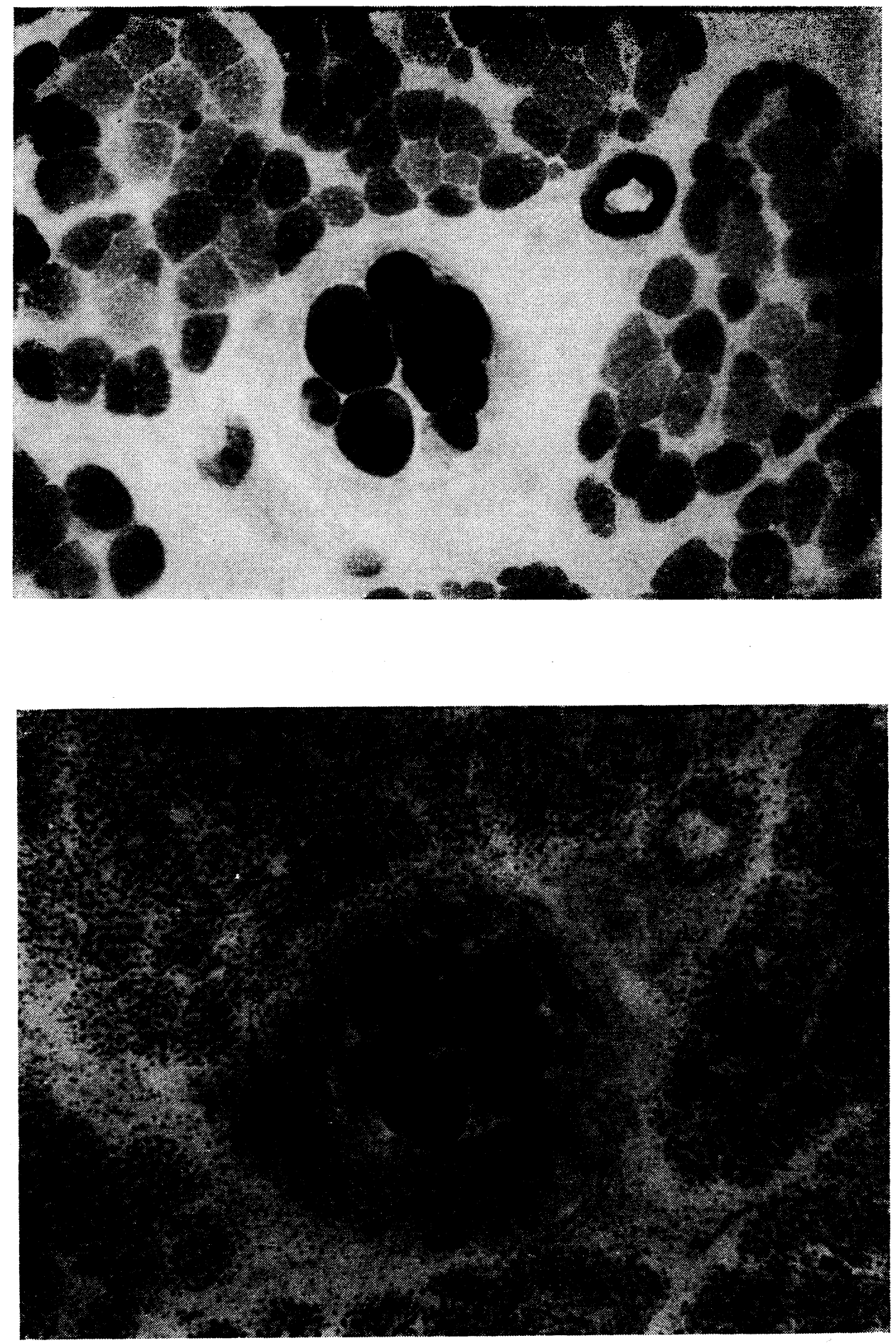
was no possibility to distinguish the fibre types according to the intensity of these reactions.

2. Muscle fibres affected by myofibrillar deficiency differed in many ways from non-affected fibres. With two exceptions, the alterations described below were of a focal character. Affected bundles occurred mostly among non-affected ones described in paragraph 1 . Thus, a negative finding in a sample does not mean necessarily that there is no alteration in another part of the muscle. Alterations were encountered most frequently in $\mathrm{m}$. gracilis, adductor and longissimus dorsi, rarely in extensor carpi radialis and pectoralis superficialis muscles.

The focal lesions had a characteristic structure. In routinely stained material, there was a defect in stainable sarcoplasm of extrafusal fibres, showing varying extent and irregular distribution. The sarcolemma seemed in those places to be separated from the sarcoplasm by a virtually empty space (Fig. 9). Similar lessions were never found in intrafusal fibres. (Fig. 11).

The $\mathrm{Ca}^{2+}$-ATPase reaction (Fig. 10) is the method of choice for quantitative evaluation of myofibrillar deficiency, since myofibrils are directly demonstrated. The method is far more convenient for routine evaluation of biopsies than electron microscopic examination, which covers a considerably smaller area. Under the given conditions ( $\mathrm{pH} \mathrm{9,4)} \mathrm{ATP} \mathrm{is} \mathrm{also} \mathrm{split} \mathrm{by} \mathrm{alkaline} \mathrm{phosphatase} \mathrm{but} \mathrm{this}$ enzyme does not occur in normal muscle fibres. It is only exceptionally present in some pathological disorders (Engel, Cunningham 1970) and if so, it can be inhibited by cysteine. In the deficient regions there were found gaps between the affected fibres and the type differentiation was less clear or inappreciable (even after acid preincubation). Where the differentiation was possible, the dark of II. fibres were affected preferentially by $\mathrm{MFH}$, while the I. fibres seemed to be very scarce or absent.

The intensity of NADH-tetrazolium reductase reaction (Fig. 12) in affected areas was also slightly decreased. The reaction product exhibited mitochondrial localization and was limited to places where myofibrils were present. No difference in reaction intensity was observed between the central and peripheral muscle fibres in the bundles. The subsarcolemmal accumulation of the reaction product usual in non affected fibres (see above) is partly or entirely absent in the fibres inside bundles. In areas with myofibrillar deficiency mitochondrial activity was also deficient.

As for glycogen the situation is different. In spaces with deficient myofibrils there was a confluent product of the PAS reaction when performed on celloidine-coated slides. The accumulated glycogen is completely digestible by saliva and soluble in formalin fixation solutions (Fig. 13).

The reaction of lipids was negative in spaces where myofibrils were absent.

In none of the muscles studied were motor end-plates affected. The reaction product was as regularly distributed as in non-affected muscles. Their size was also unchanged (Fig. 14).

Fig. 5.

Detail from Fig. 1. Approximately equal size of both fundamental types of fibres. Magnification $400 \times$.

Fig. 6.

Non-affected muscle (m. extensor carpi radialis). Extrafusal fibres, NADH-tetrazolium reductase. Accumulation reaction product on the periphery of muscle fibres. Magnification $600 \times$. 


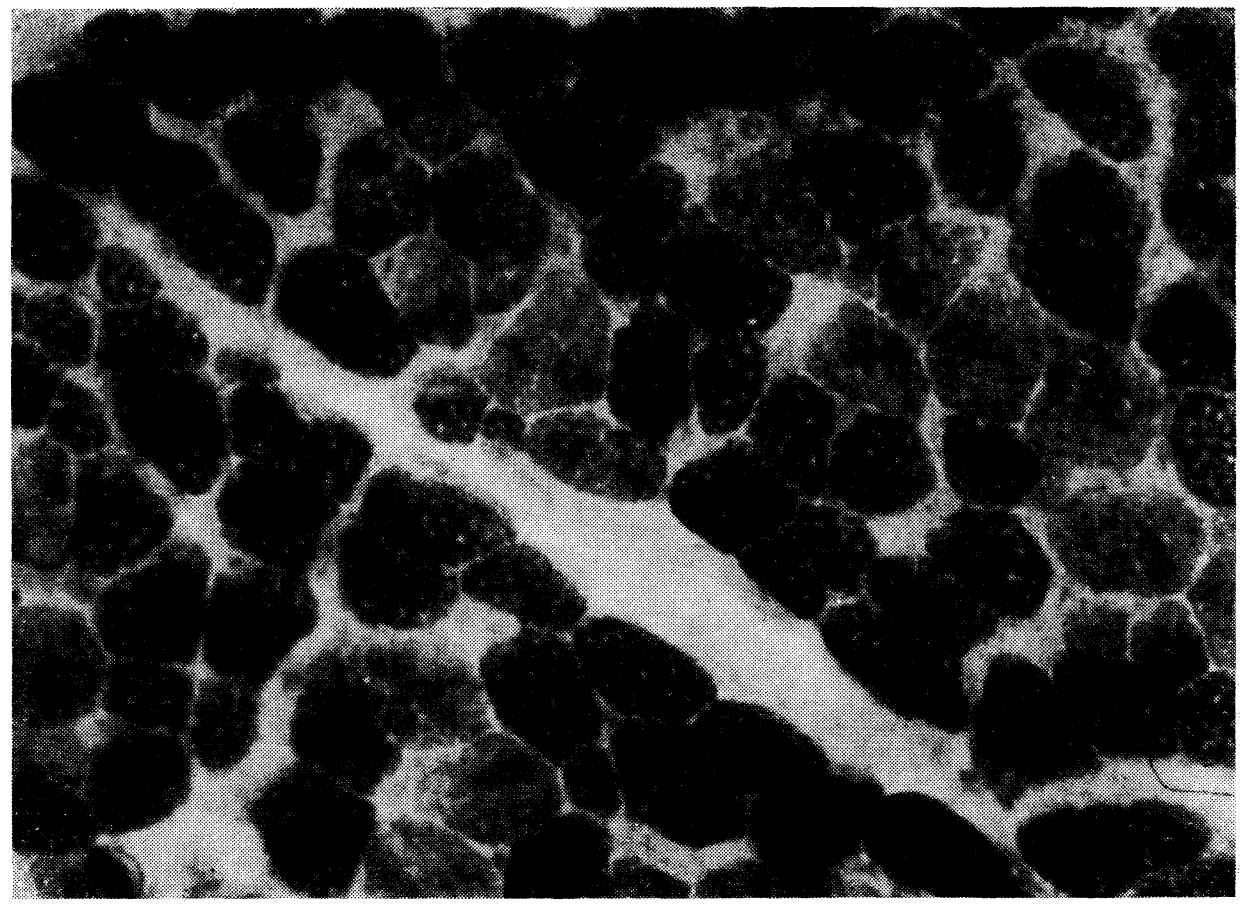

80 T6- a

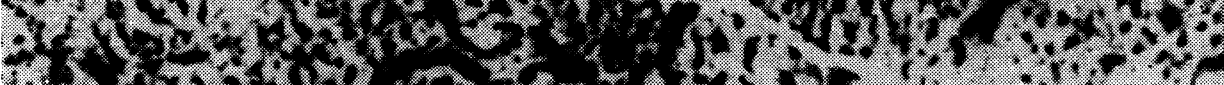
1.

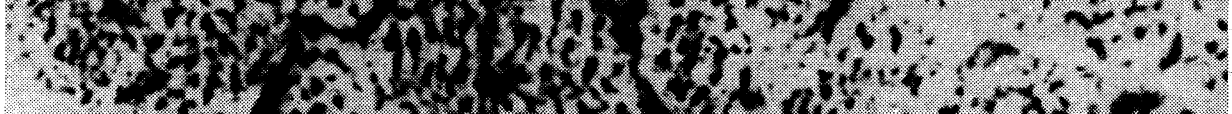

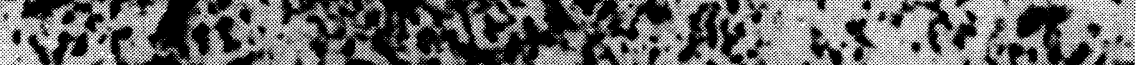

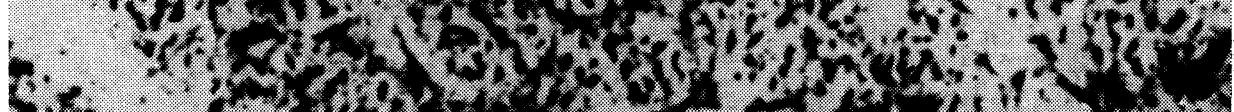

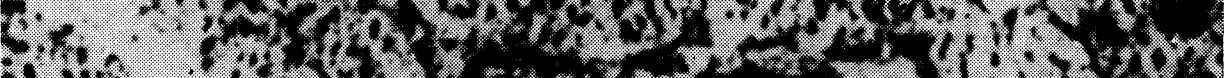

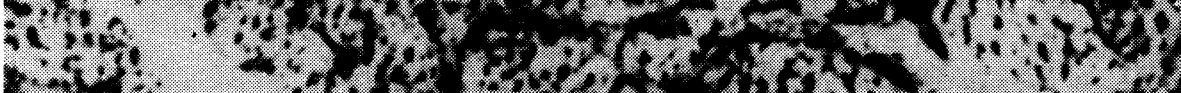

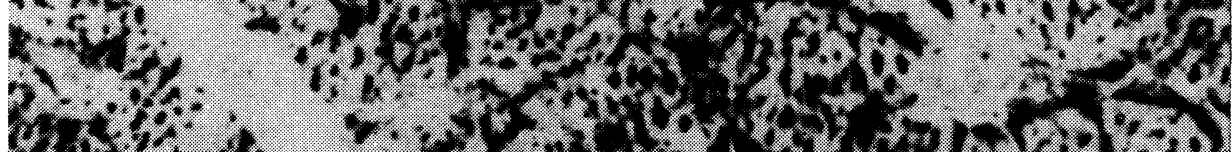
\begin{tabular}{ll}
6 \\
\hline
\end{tabular}

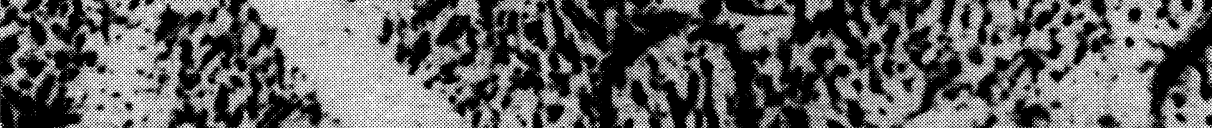

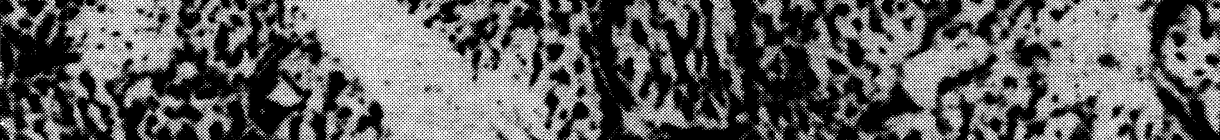

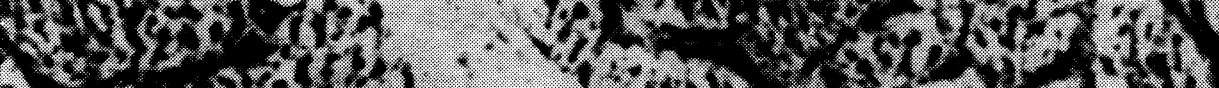

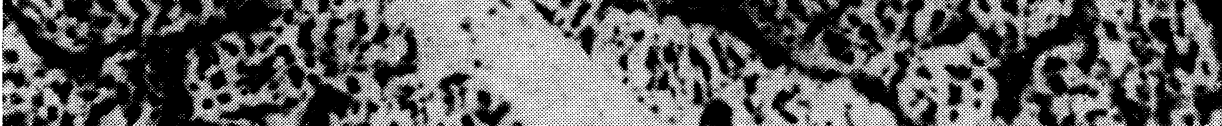

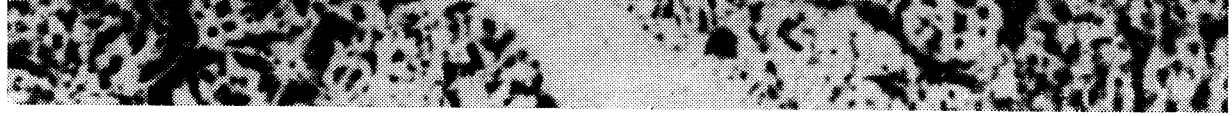


Where muscle spindles were found in affected regions abnormalities in intrafusal fibres were never observed.

Unless hypoplasia was connected with additional alterations no lysosomal activation (acid phosphatase, non-specific esterase) could be registered.

3. Regressive and structural changes. Some muscles, particularly gracilis and adductor, were affected inconstantly by additional alterations: variability in diameter of fibres (difficult to evaluate if associated with myofibrillar deficiency), major polymorphy of nuclei, their swelling, higher number of central and internal nuclei, sporadically even flocculation as well as basophilia of fibres. The histochemical correlation to these changes was represented by a distinct activation of histocytes strongly reacting for acid phosphatase and non-specific esterase in lysosomal localization. The lysosomal reaction could be also observed to a minor extent in the endothelium of blood vessels and in the muscle fibres themselves. A secondary consequence of the structural changes described is also NADH-tetrazolium reductase reaction. The reaction of motor end-plates was unaffected in those areas.

\section{Discussion}

1. Structure of affected fibres. The present results are well comparable to studies on the ultrastructure of affected fibres performed by Deutsch and Done (1971) and Bergmann (1976). The $\mathrm{Ca}^{2+-A T P a s e}$ reaction at $\mathrm{pH} 9.4$ without preincubations demonstrates myofibrils or their absence in muscle fibres directly. In deficient spaces, myofibrillar absence accompanied by negative mitochondrial reactions confirmes the electron microscopic findings. Different opinions have been expressed concerning the material filling out the spaces. While Deutsch and Done (1971) considered the granular material partly as glycogen, partly as ribosomes, Bergmann (1976) described (in this hypoplastic fibre type) accumulation of granules representing glycogen and its split products while ribosomes were partly deficient. The findings were put in relation to defective synthesis of contractile proteins and stagnation in the formation of myofibrils. As for glycogen granules, he demonstrated that they were often conglomerated to diffuse shapeless deposits. Our findings of PAS-positive material in the deficient spaces corelate well to these data. Glycogen seems to be strongly soluble and can be completely removed by digestion with saliva amylase. In this regard it reacts similarly to glycogen in third type glycogenosis. It is possible that the glycogen is partly split as suggested by Bergmann. The question remains whether the finding is or is not related to the data of Thurley and Done (1969), who described variation in the intensity of glucan-phosphorylase reaction in deficient fibres.

2. Fibre type development in normal and affected muscles. Our findings of differentiation of the unaffected muscle fibres into the two basic types

Fig. 7.

Non-affected muscle (m. extensor carpi radialis). Motor-end plates demonstrated by acetylcholinesterase reaction (thiocholine method) in longitudinal fibres. Magnification $200 \times$.

Fig. 8.

Non-affected muscle (m. extensor carpi radialis). Motor-end plates demonstrated by azocopulation method with alpha-naphthylacetate. Muscle fibres cut perpendicularly. Magnification $400 \times$. 

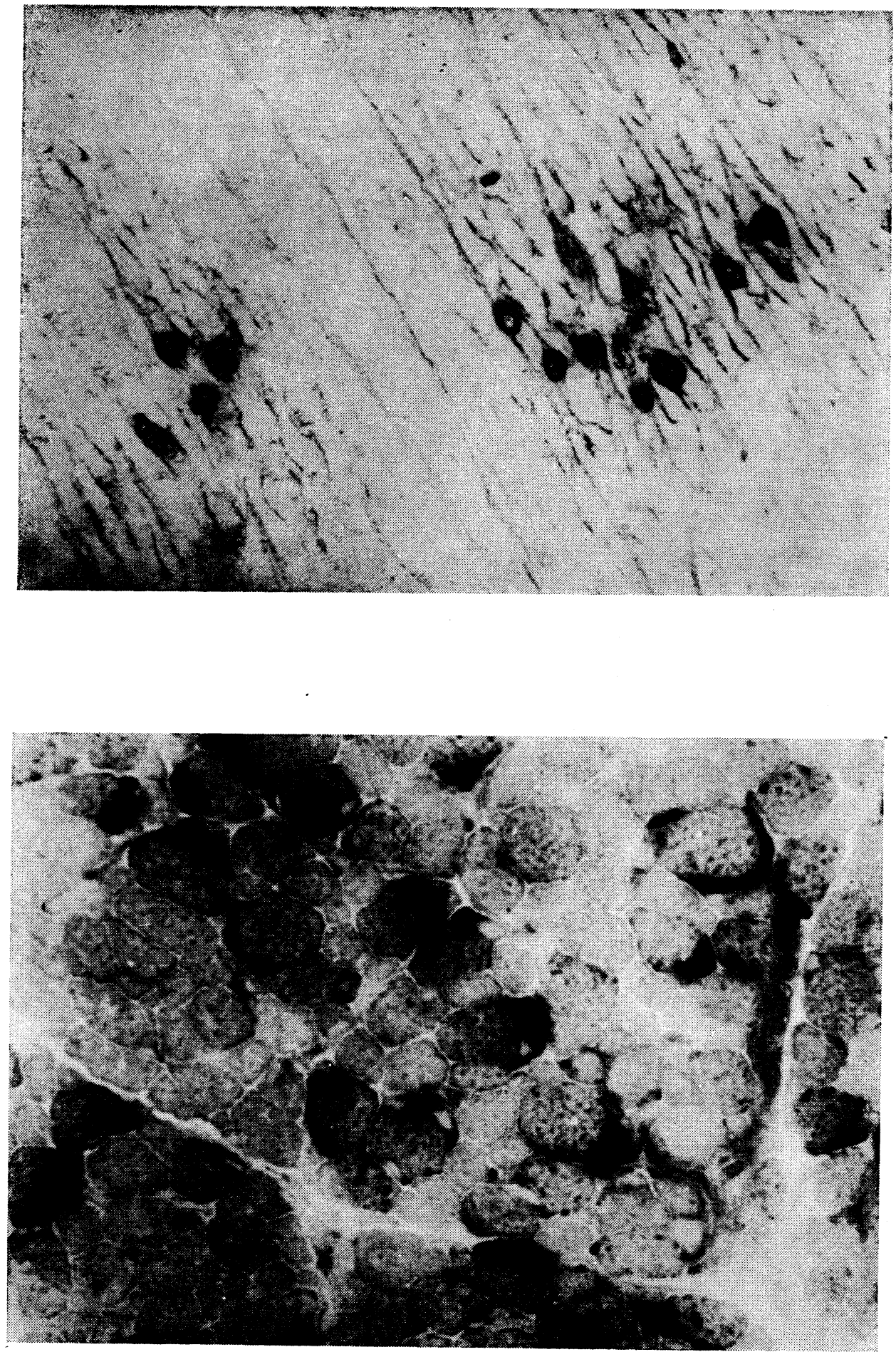
(alkali-stabile and acid-labile on the periphery of primary bundles, and alkali-labile and acid stabile in the center) according to the classification of Guth and Samaha (1969), are in accordance to the data of Schlotke and Koch (1978) and of Swatland (1975). A shmore et al. (1973) found differences in the resistance of $\mathrm{Ca}^{2+}$-ATPase reaction against acid preincubation even in fetal muscle fibres. Cooper et al. (1970), on the other hand, investigating postnatal development of muscle fibres in piglets, did not observe any difference in intensity of histochemical reactions at the first day post partum. Red fibres with moderate intensity of ATPase and intensive reaction for NADH-tetrazolium reductase were detectable in the first week, while white fibres (strong ATPase and moderate $\mathrm{NADH}$-tetrazolium reductase) and intermediate ones (both reactions strong, moreover subsarcolemmal accumulation of NADH-tetrazolium reductase) were differentiated later. The question remains whether our findings of some fibres with subsarcolemmal accumulation of the reaction product of tetrazolium reductase activity may correlate to the prospective intermediary fibres mentioned above.

In piglets aged one day Swatland (1975) observed only in some bundles indications of the type differentiation according to $\mathrm{Ca}^{2+}-\mathrm{ATPase}$ reaction. He emphasized that the histochemical demonstration of the ATPase may be influenced by contraction of muscle fibres before their deep-freezing, and by the participation of mitochrondrial $\mathrm{Ca}^{2}+-\mathrm{ATPase}$ in the reaction, and, consequently the picture need not correspond to the rest myofibrillar ATPase activity. This speculation was not based on experimental results. More plausible seems to be the explanation of all findings quoted our observations included, that the differentiation from day 1 of life does not necessarily involve all muscle fibres simultaneously. The high level of differentiation in our material obviously resulted from the fact that some piglets older than one day were also processed.

Foci with myofibrillar deficiency showed a decreased difference in intensity of the ATPase reaction - and similarly of the tetrazolium reductase reaction - between peripheral and central fibres of bundles. In addition, there were almost no fibres with peripheral agglomeration of reaction product, i. e. presumed intermediary fibres. Type differentiation was less pronounced in the deficient areas but it is the second population of fetal myofibres that seems to be affected by myofibrillar hypoplasia. The delayed differentiation seems to be an integral part of the reversible dysmaturity, as the lesion studied was characterized by Deutsch and Done (1971).

3. Structural myopathic changes

Structural, regressive and progressive changes in extrafusal muscle fibres, accompanied by the lysosomal activation of histiocytes, were non-constant findings in our material, and they correspond to the Bergmann (1976) dystrophic fibre type. In our opinion, they do not represent any integral part of the disease, but they are more probably secondary to the changes described above.

Fig. 9.

Affected muscle (m. gracilis). Routine staining with hematoxyline-eosine. Area of large hypoplasia of myofibriles. Magnification $800 \times$.

Fig. 10.

Affected muscle (m. gracilis). Myofibrillar deficiency smaller, myo-ATPase. Specific activity not evidently affected, smaller or no difference in intensity of reaction compared with the norm.

The reaction shows the extent of myofibrillar deficiency. 


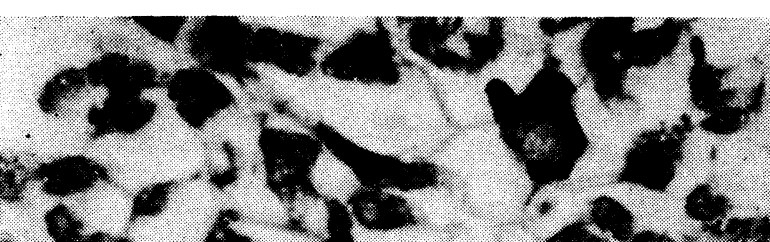

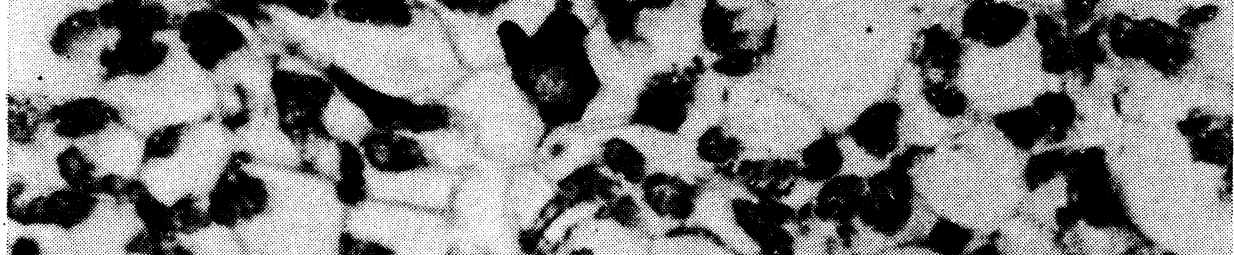
$6+5002505$

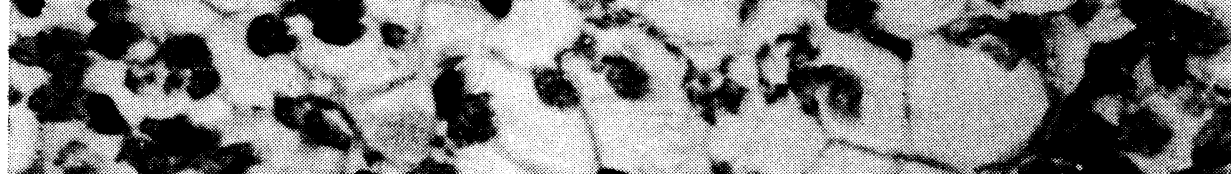
ats

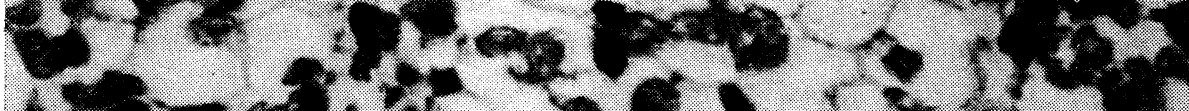

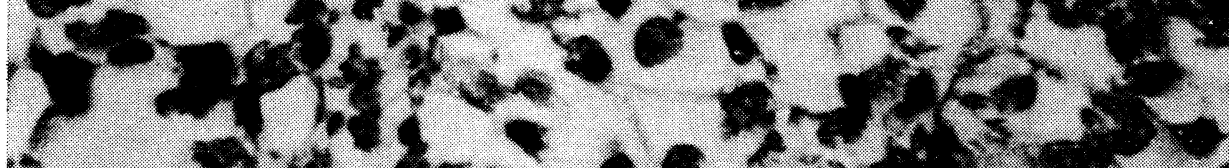

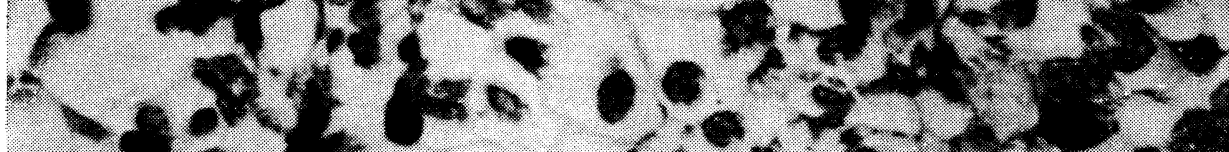
$-12=6 x^{2}-5$ - atrat atos

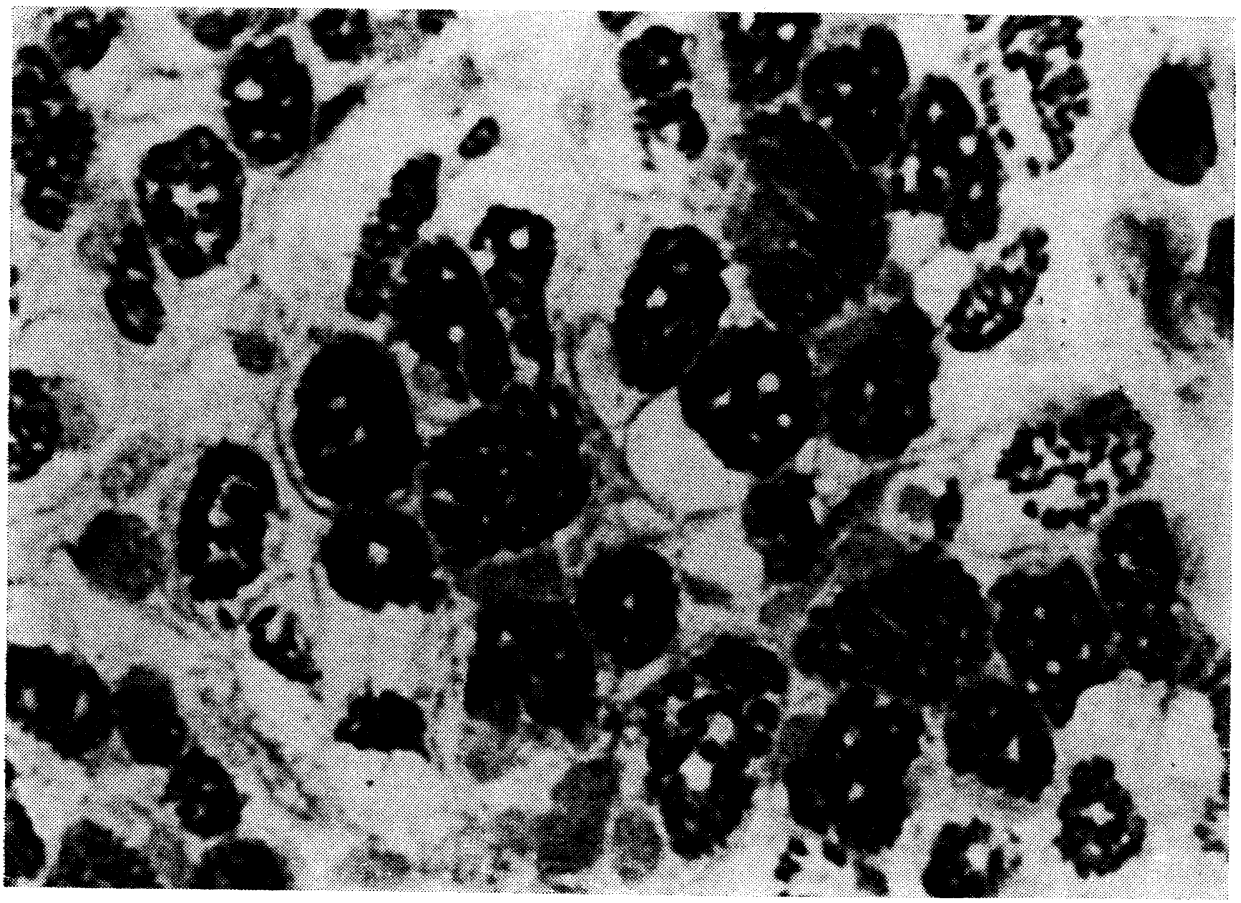




\section{Histochemická charakteristika syndromu svalové slabosti končetin novorozených selat (Splayleg syndrome)}

U jedno- až třídenních selat s přiznaky tzv. splayleg syndromu s nálezem myofibrilární hypoplasie a u 4 klinicky zdravých selat $\mathrm{z}$ téhož chovu byly histologicky a histochemicky vyšetřeny $\mathrm{mm}$. extensor carpi radialis, pectoralis superficialis, triceps brachii, gracilis, adductor, biceps femoris a longissimus dorsi. Kromế přehledného barvení byly provedeny reakce $\mathrm{k}$ histochemickému průkazu myozínové ATP-ázy, NADH-tetrazolium reduktázy, nespecifické esterázy a cholinesterázy, glykogenu a lipidů.

Nepostižená extrafuzální vlákna ukazuji v reakci myozínové ATP-ázy podle její intenzity 2 typy: silněji reagující vlákna, uložená převážně na periferii primárních svazečkủ a slaběji reagující, ležící více $\mathrm{v}$ jejich centrech. Intenzita reakce NADH-tetrazolium reduktázy neodlišila tyto 2 typy vláken, lokalizace byla evidentně mitochondriální a okrskovitě byla nalezena intenzívní reakce i na periferii vláken. Intenzita reakce na glykogen a na lipidy byla vcelku stejná u všech vláken. Motorické ploténky (znázorněné azokopulační (azo-dye) metodou alfa-naftylacetátem i histochemickou detekcí acetylcholinesterázy) jsou pravidelně distribuovány a vykazují normální parametry. Intrafuzální vlákna vykazují dosti intenzívní, většinou uniformní reakci NADH-tetrazolium reduktázy a graduovanou, silnou až velmi intenzívní reakci myozínové ATP-ázy.

Změny deficitních vláken představuje absence myo-ATP-ázové reakce v místech deficitu myofibril, snížení až vymizení rozdílů $v$ intenzitě reakce mezi centrálně a periferně uloženými vlákny a absence reakce NADH-tetrazolium reduktázy $\mathrm{v}$ místech deficitu. Naproti tomu se $\mathrm{v}$ těchto místech akumuluje glykogen. Reakce motorických plotének ani jejich velikost a distribuce nebyla změněna. $U$ intrafuzálních vláken deficit myofibril nebyl zjištěn a ani intenzita studovaných reakcí nebyla změněna.

Гистохимическая характеристика синдрома мышечной слабости конечностей новорожденных поросят (Splayleg syndrome)

У поросят в возрасте один-три дня с признаками т. н. сплейлег синдрома и с диагнозом миофибриллярной гипоплазии и в случае 4 клинически здоровых поросят той же фермы пдоводились гистологические и гистохимические обследования $\mathrm{mm}$. extensor carpi radialis, pectoralis superficialis, triceps brachii, gracilis, adductor, biceps femoris, longissimus dorsi. Помимо окраски проводились реакции для гистохимической идентификации миозинной ATP-азы, NADH-тетразол редуктазы, неспецифической әстеразы и холинэстеразы, гликогена и липидов.

Незатронутые әкстрафузальные волокна на основе реакции миозинной АТР-азы, исходя из ее интенсивности, делятся на два типа: интенсивнее

Fig. 11.

Affected muscle. Stained by hematoxyline-eosine. Intact intrafusal fibres with deficient extrafusal fibres (arrow). Magnification $400 \times$.

Fig. 12.

Affected muscle (m. adductor). NADH-tetrazolium reductase. Negative reaction in areas with myofibrillar deficiency, evident mitochondrial location in myofibriles. Magnification $400 \times$. 

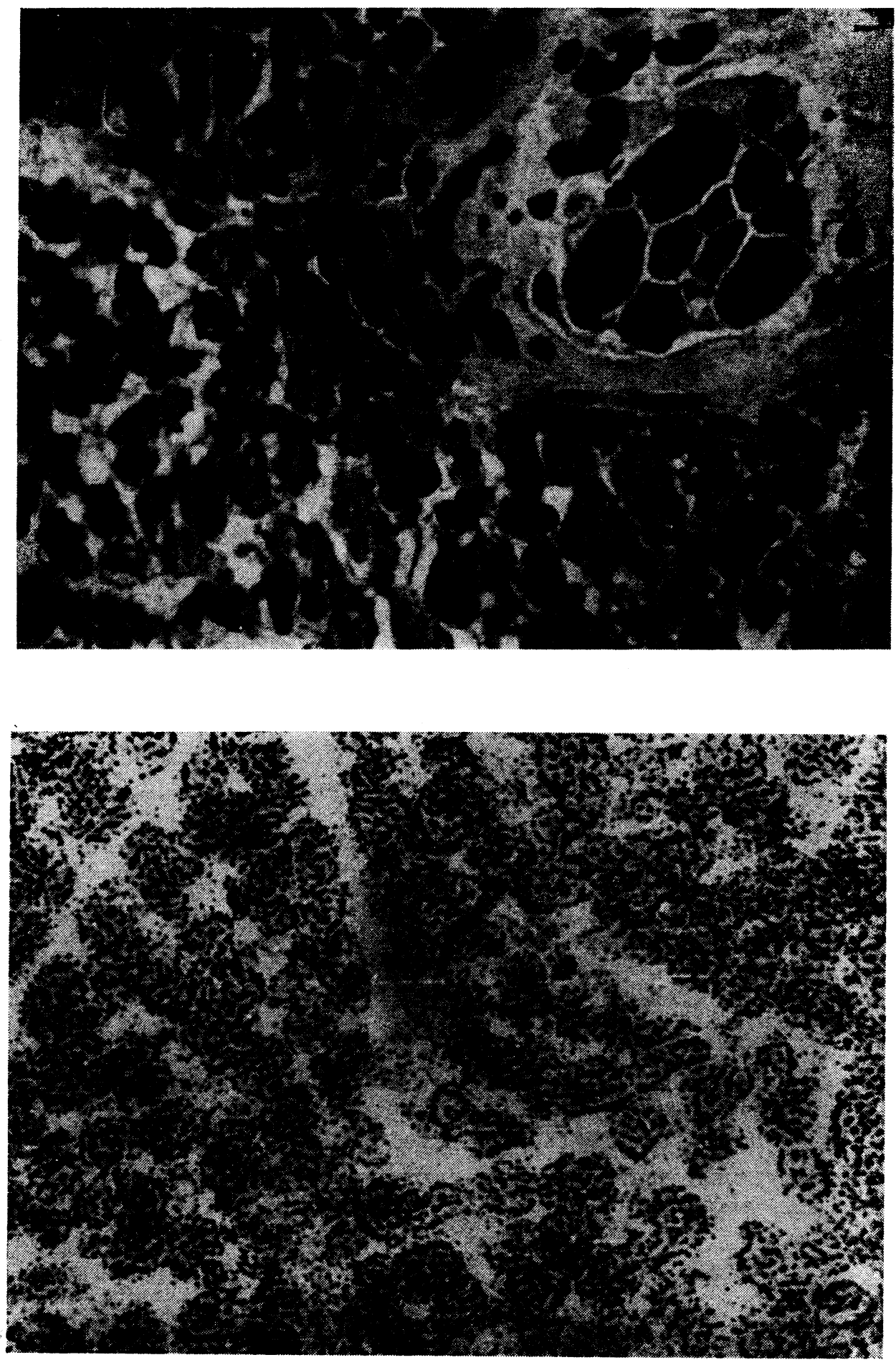
реагирующие волокна, расположенные преимущественно на периферии первичных пучков, и менее интенсивно реагирующие волокна, расположенные больше в центре пучков. Интенсивность реакции NADH-тетразол редуктазы не отличала приведенные два типа волокон, место расположения было явно митохондриальным и по отдельным участкам была выявлена интенсивная реакция также на периферии волокон. Интенсивность реакции на гликоген и липиды была в общем одинаковой у всех волокон. Моторные блятки (изображенные азокопуляционным [азо-дай] методом альфа-нафтиласетатом и гистохимическим детектированием ацетилхолинэстеразы) распределены регулярно и отличаются нормальными параметрами. Интрафузальные волокна отличаются двольно интенсивной, в большинстве случаев однотипной реакцией NADH-тетразол редуктазы и градуированной, сильной вплоть до весьма интенсивной реакцией миозинной ATP-азы.

Изменение дефицитных волокон представляет отсутствие мио-АТР-азной рєакции в местах недостатка миофибрилл, понижение, даже исчезновение разницы интенсивности реакции между центрально и на периферии расположенными волокнами, отсутствие реакции NADH-тетразол редуктазы в местах дефицита. В данных местах в противовес этому скопляется гликоген. Реакция моторных блятек, их величина и дистрибуция остались неизменными Дефицит миофибрилл в случае интрафузальных волокон не был установлен, интенсивность изучаемых реакций осталась также без изменений.

\section{References}

ASHMORE, C. R. - ADDIS, P. B. - DOERR, L.: Development of muscle fibers in the fetal pig J. Anim Sci., 36, 1973: 1088-1093.

BERGMANN, V.: Elektronmikroskopische Befunde an der Skelettmuskulatur von neugeborenen Ferkeln mit Grätschstellung. Arch. exper. Vet. Med., 30, 1976: 239-260.

COOPER, C. C. - CASSENS, R. G. - KASTENSCHMIDT, L. L. - BRISKEY, E. J.: Histochemical characterization of muscle differentiation. Developm. Biol., 23, 1970: 69-84.

DEUTSCH, K. - DONE, J. T.: Congenital myofibrillar hypoplasia of piglets: Ultrastructure of affected fibers. Res. vet. Sci., 12, 1971: 176-177.

GUTH, L. - SAMAHA, F. J.: Qualitative differences between actomyosin ATPase of slow and fast mammalian muscle. Exp. Neurol., 25, 1969: 138-152.

LUKÁŠ, Z. - DVOŘÁ, K.: Histochemické a kvantitativní metody $\mathrm{v}$ bioptickém vyšetřování kosterního svalstva. Ćs. patol., 13, 1977: $21-31$.

PADYKULA, H. A. - HERMAN, E.: Factors affecting the activity of adenosine triphosphatase and other phosphatases as measured by histochemical techniques. J. Histochem. Cytochem., 3, 1955: $161-169$.

PADYKULA, H. A. - HERMAN, E.: The specifity of the histochemical method for adenosin triphosphatase. J. Histochem. Cytochem., 3, 1955: 170-183.

PATTERSON, D. S. P. - ALLEN, W. M.: Biochemical aspects of some pig muscle disorders. Br. vet. J., 128, 1972: $101-110$.

PIVNÍK, L. - KAMAN, J.: Aktuální onemocnění svalstva prasat a jejich význam pro produkci masa ve velkochovech. Veterinářství, 24, 1974: 156-158.

PIVNÍK, L. - KAMAN, J.: Výzkum některých poruch motility novorozených selat. Project report VI-6-4/8, 67 pp., University of Veterinary Science, Brno, 1975.

Fig. 13.

Affected muscle (m. adductor). PAS reaction without digestion. Confluent glycogen reaction apart from intact myofibriles, filling areas of myofibrillaris deficiency. Magnification $800 \times$.

Fig. 14.

Affected muscle (m. gracilis). Acetylcholinesterase. Motor-end plates of usual shape, size and reaction. Magnification $400 \times$. 

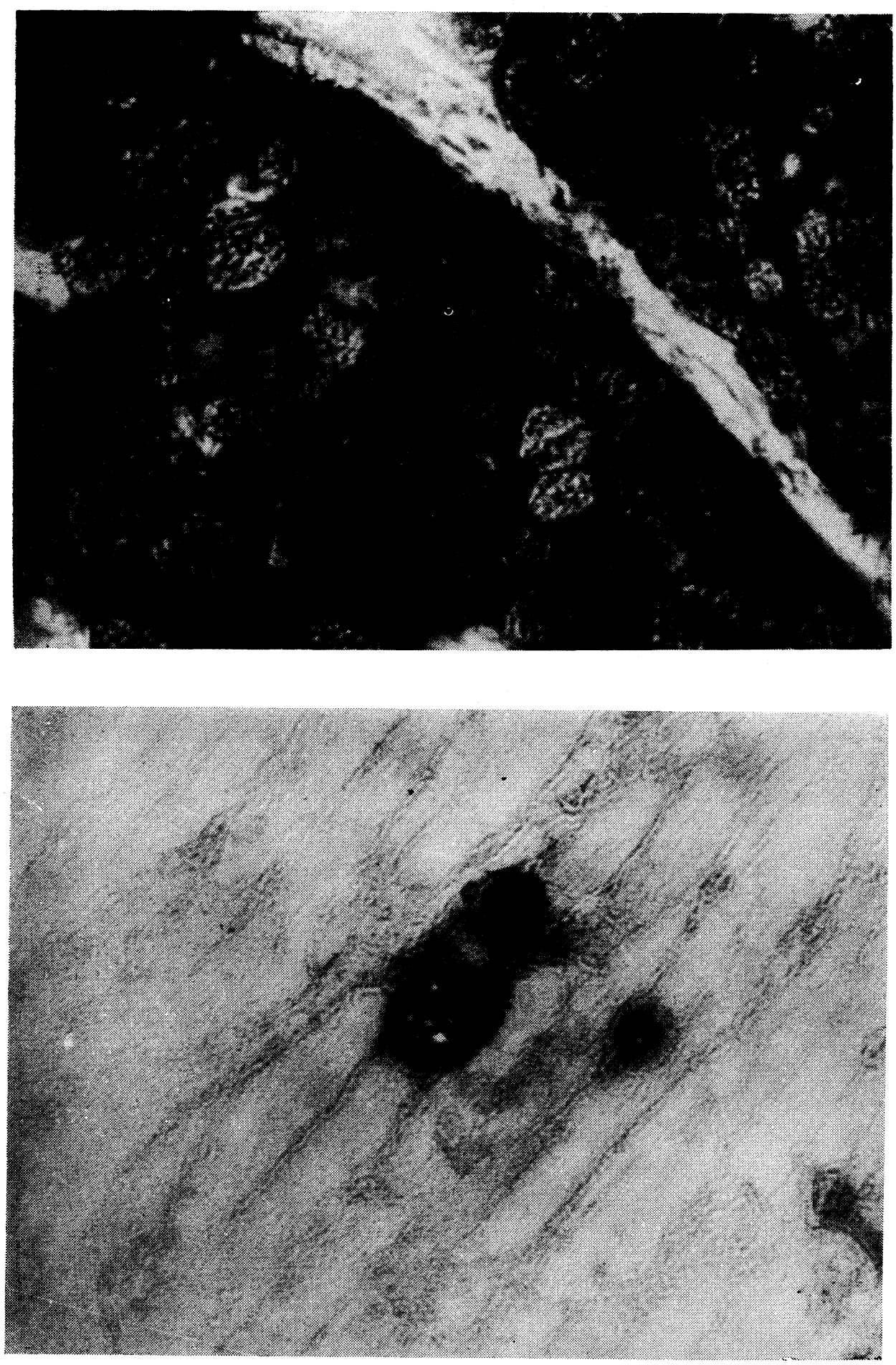
PIVNfK, L. - KAMAN, J.: K problematice svalové slabosti končetin novorozených selat. Veterinářství, 27, 1977: 25-28.

PIVNfK, L. - KAMAN, J.: Využití výsledkủ výzkumu svalové slabosti končetin novorozených selat. Veterinářství, 27, 1977: 78-79.

SCHLOTKE, B. - KOCH, F.: Histochemische Untersuchungen zur Entwicklung der Skelettmuskulatur des Ferkels in der Neugeborenenphase. Zbl. Vet. Med., A, 25, 1978: 129-137.

SWATLAND, H. J.: Developmental disorders of skeletal muscle in cattle, pigs and sheep. Vet. Bull., 44, 1974: 179-202.

SWATLAND, H. J.: Myofibre number and myofibrillar development in neonatal pigs. Zbl. Vet. Med., A, 22, 1975: 756-763.

SWATLAND, H. J.: Histochemical development of myofibers in neonatal piglets. Res. Vet. Sci., 18, 1975: 253-257.

SWATLAND, H. J. - CASSENS, R. G.: Prenatal development, histochemistry and innervation of porcine muscle. J. Anim. Sci., 36, 1973: 343-354.

THURLEY, D. C. - DONE. J. T.: Histology of myofibrillar hypoplasia of new born pigs. Zbl. Vet. Med., A, 16, 1969: 732-740.

THURLEY, D. C. - GILBERT, F. R. - DONE, J. T.: Congenital splayleg of piglets : myofibrillar hypoplasia. Veter. Rec., 80, 1967: 302-305. 